Article

\title{
Evangelicals' Sanctification of Marriage through the Metaphor of Jesus as a Husband
}

\section{Julie A. Zaloudek}

Department of Human Development and Family Studies, University of Wisconsin-Stout, 124 HERH, Menomonie, WI 54751, USA; E-Mail: zaloudekj@uwstout.edu; Tel.: +1-715-232-2102;

Fax: +1-715-232-2524

Received: 15 March 2014; in revised form: 26 June 2014 / Accepted: 17 July 2014 /

Published: 29 July 2014

\begin{abstract}
Researchers have examined how perceiving marriage as "sacred" or believing God is manifest in marriage is associated with marital functioning and satisfaction, but little is known about how biblical family metaphors (e.g., God is father) inform Christians' interpretations of family relationships. Few studies explore the perspective of individuals who believe in, interpret and apply these metaphors to their relationships. This study uses Hermeneutic Theory to examine how Evangelicals apply the metaphor of Jesus as husband and the church as bride to their intimate relationships and spirituality. Qualitative interviews with 15 Evangelicals explored the meaning, interpretations, and processes of marital relationships in light of the Christ-groom God image. Participants indicated many ways the metaphor was useful: value partners more; invest more in the relationship; strive to demonstrate love, patience, etc. toward partners; and guidance in relationship structuring. They discussed how their couple relationships opened positive and negative possibilities for relating to God. Gender hierarchy and implication that husbands are the "head" or "Christ" figure in marriage caused incongruence for some participants as did the difficulty of comparing a person or human relationship to a spiritual metaphor. Application, implications, and ideas for future research are discussed.
\end{abstract}

Keywords: sanctification; Evangelical; Christian; marriage; couples; gender; metaphors 


\section{Introduction}

Wives, submit to your husbands as to the Lord. For the husband is the head of the wife as Christ is the head of the church, his body, of which he is the Savior. Now as the church submits to Christ, so also wives should submit to their husbands in everything. Husbands, love your wives, just as Christ loved the church and gave himself up for her... In this same way, husbands ought to love their wives as their own bodies. He who loves his wife loves himself. (Ephesians 5:22-28, NIV).

Family metaphors are commonly used within Christianity to describe God and the varied relationships of God with people. In many cases, these metaphorical family relationships are expressed as direct examples of how family members do (or ought to) relate to each other. God as a pursuant lover and Israel as a bride is a common Old Testament family metaphor, and this continues in the New Testament where Jesus is referred to as the bridegroom to a Church-bride. The metaphor was taken to a personal (and, some would argue, proscriptive) level when the author of Ephesians directed husbands and wives to act in accordance with the Jesus-groom and Church-bride metaphor with husbands as head of the wife "as Christ is the head of the church," and to how married couples "should" relate: husbands should love sacrificially as Christ and wives should submit as the church to Christ.

This single extrapolation of that metaphor continues to be a foundation for Evangelical Christian theology regarding marital structure and relating, and the topic of books, sermons, and materials to help engaged and married couples establish their relationships. In his science fiction novel entitled, That Hideous Strength, C.S. Lewis's spiritual leader character (called The Director) advises an unhappily married woman to submit to her husband [1]. The Director tells her that she could have avoided males by choosing not to marry and remaining a virgin and continues, "But the masculine none of us can escape. What is over and beyond all things is so masculine that we are all feminine in relation to it" ([1], pp. 315-16).

Focus on the Family - the most prominent and enduring source of family information for conservative Christians - is heavily infused with the Christ-groom/Church-bride metaphor and the suggestion that Christians should model their marital relationships from it, at least to some degree [2-4]. The author says of marriage, "Together and rightly ordered, their united differences ignite the power and glory of creation itself, which is the consummate activity of God from the beginning" [2]. Just as Eve was taken from Adam to fully reflect the "image of God", marriage is required for a complete revelation of God's essence. Later the author relates the metaphor spiritually, saying, "But first, we must marry God — not just legally and judicially, but in truth" [3]. The author strenuously contends that heterosexual, monogamous marital union is necessary to reveal God's nature and intended relationship with humans and must be founded on a holy union with God. This illuminates why the institution of marriage and doing marriage in the "right" way is a very high stakes proposition for Evangelical Christians, and it is the metaphor of the Christ-groom/Church-bride that is largely used to define what is "right" in marriage.

Although Evangelicals embrace a more literal application of this metaphor to marriage and spirituality compared to Mainline and Liberal Christians, the ways that meaning is constructed and invoked on couple relationships and spirituality is diverse among them. Research has revealed disparities between professed gender ideologies of religious leaders and every day practices of 
Evangelicals [5]. There are also disparities between individual's beliefs and practices. One researcher found a united language about gender roles in a conservative Evangelical congregation, but also contradiction and complexity [6]. The congregation under study embraced traditional gender ideologies in general, but while women supported traditional female roles, they rejected traditional roles for husbands who were expected to be actively involved in family life and be emotionally expressive. Contemporary Evangelicals embrace a more traditional but largely symbolic ideal of male headship but a more pragmatic egalitarianism in how they act out their relationships and family roles, such as wives managing family finances, but both the husband and wife declaring that the husband has the final say [7]. This fits with findings that conservatives articulate a more traditional gender ideology but also an aggressive agenda to make men more active participants in family life [8]. These studies provide insights into the nuanced beliefs and behaviors of Evangelicals with regard to gendered relationships, but little work has been done to explore how these individuals grapple with reconciling this prominent metaphor with their lived relationships and spirituality.

Despite radical changes in society and the family over the past several decades characterized by women becoming more educated, mothers working outside the home, wives bringing home salaries comparable to husbands, and couples embracing more egalitarian models of marriage, Evangelical leaders have continued to use this metaphor as a primary way of instructing Evangelicals about how to model "Christian marriage". This study focuses on Evangelicals because they are more likely to emphasize hierarchy and authority via specific biblical metaphors compared to non-Evangelical Christians who tend to emphasize metaphors in keeping with the "Golden Rule" [8]. How do Evangelical men and women reconcile their more literal interpretation of the Bible and application of this metaphor with their own marital relationships and spirituality in a post-feminist society? I use Hermeneutical Theory to argue that participants' presuppositions and lived experiences shape their interpretations of the metaphor even as they use the metaphor to make meaning of their marital relationships and spirituality.

\section{Background}

\subsection{Divergent Interpretations of Gendered Metaphors among Evangelicals}

Even as cultural norms and views of contemporary Christians shift, the perceived masculinity of God as demonstrated through the metaphors of "God the Father" and Jesus the "son of God" has implications for family relationships and structure that persist for Evangelicals. One theologian claims that women picture the church by modeling submission, and men picture Christ by modeling humble leadership through service and sacrifice [9]. In what the theologian calls "spiritual reality," both men and women respond to the Christ-husband in the feminine role of submission, as suggested by C.S. Lewis's novel fifty years earlier [1]. Evangelical authors consistently rely on the creation story and Christ-groom/Church-bride metaphor to discuss the meaning of marriage and proscribe behaviors, though interpretations are diverse. Analysis of Evangelical family manuals, commentators, and fiction reveal many gender ideologies based on the same scripture passages [10-12]. This variety of interpretations was even exemplified by the Promise Keepers, an evangelical men's movement popular in the 1990s [13]. One author reviewed books on masculinity and cultural products of the Promise Keepers 
and found four gender ideologies: traditionalist (hierarchical), psychological archetypes (primarily modifications of Jung), biblical feminist (egalitarian), and practical counseling (do what works) [13].

Evangelical feminist theologians and writers have also contributed to the discussion of God in gendered family metaphors and its implications. Unlike feminists who have rejected the Bible as inerrant in favor of a more egalitarian ideology, evangelical feminists view the Bible as the inerrant and divinely inspired solution to spiritual issues as well as for oppression in the home, church, and society. Evangelical feminists rely on hermeneutical methods of interpretation of scripture and argue for more inclusive gendered family metaphors for God, the development of feminine metaphors in scripture that they consider neglected, and fresh interpretations of masculine and feminine family metaphors for God [14-18]. These authors also critique the traditionally gendered way of interpreting the metaphors, claiming that they are harmful to relationships and may encourage projecting negative qualities onto God from past experiences with men [14,17]. One author claims that there is a powerfully compelling implication to thinking of God as male: "If God is male, then the male is God" ([17], p. 39). She challenges that the Christ-groom/Church-bride metaphor encourages girls to be passive and irresponsible and boys to be prideful and domineering. Evangelical feminist interpretations have been strongly criticized by more conservative Evangelicals who view it as a threat to the "proper" structuring of marriage as established by God through these metaphors [19]. We know that the Christ-groom/Church-bride metaphor continues to be heavily used in theological discussions and Evangelical rhetoric on marriage, but does it impact how Evangelicals make meaning of and live out their marital relationships and spirituality? The concept of sanctification provides an explanation for how viewing a natural object as "sacred" can impact behaviors and perceptions of that object.

\subsection{God Image Metaphors and Sanctification of Marital Roles and Relationships}

Sanctification is the inscribing of spiritual character or significance to natural matters [20]. This may happen through manifestations of God-when an object is a manifestation of a person's image, beliefs, or experiences of God-or through sacred qualities that attribute qualities typically associated with the divine (e.g., blessed, miraculous) to natural objects. Living within the framework of family metaphors for God is a very specific example of sanctification. Couple relationships may be perceived as manifestations of the nature of God or the ideal structure of family and society, as illustrated by the Covenant Marriage movement that seeks to use marriage to demonstrate to society their perception of God's relation to humanity [21]. Marriages may also be perceived as having sacred qualities, and there is a body of evidence to suggest that sanctifying family relationships has potential to alter the experience and actions of people within those relationships.

College students who reported greater beliefs of sanctification regarding sex were more likely to report positive feelings about sexual activity and also more likely to have engaged in premarital sexual activity [22]. Newlyweds who perceived spiritual attributes to their sexual relationships were more likely to report positive sexual outcomes like satisfaction, marital intimacy, and spiritual intimacy [23]. Sanctification was linked to more positive and less negative feelings toward marital partners, especially among couples experiencing financial stress [24]. Married couples experiencing perceived inequity in their marriages were less likely to experience marital dissatisfaction and conflict when they 
had higher levels of sanctification [25]. It may be that sanctification is a mechanism whereby couple's investment in each other and the relationship is enhanced.

In a sample of Christians, Jews, and Muslims, people who considered their marriages to be sanctified thought of God being present in their marriages [26]. Some sanctified their relationships through theology and focused on the teachings of their faith and its application to their marriage. Others cited the importance of following the example of Jesus and emphasized relational characteristics of unconditional love, forgiveness, and patience in marriage.

Sanctification may also present religious people with psychological risks, like when a family structure or function falls outside of what is defined as sacred, such as gender traditional households where the woman is the spiritual leader [20]. Conflict may emerge from within a family when there is disagreement on what kind of structures or roles are blessed or sanctified by God. When a relationship or family tie is severed (e.g., divorce), the sense of loss may be more acute if the relationship was believed to be sanctified and has been associated with increased levels of depression, mediated by spiritual coping [27].

These findings suggest that thinking of family relationships in light of family based God images may have implications for family life. God images have been found to be better predictors of people's beliefs (e.g., political affiliation, abortion views, belief in evolution, position on gay marriage, etc.) more than their religious affiliation, church attendance, and other common predictors [28].

Studies on sanctification have been illuminating about the mechanism by which religious beliefs influence the everyday lives of families, but few have looked at the process of sanctification from the perspective of the individuals themselves. How do individuals go about applying spiritual metaphors to their natural relationships? How do they resolve incongruences between the spiritual and natural phenomena? How do they deal with their own success or failure to sanctify their relationships or disparities in their perception and their partner's perception of what is sacred or good or right? How might marital sanctification be projected back onto spiritual experiences and relating to God?

This study invited participants to describe in rich detail the process by which they sanctify their relationships. In-depth, phenomenological interviews inquired into their experience of the Christ-groom God image, how they use the metaphor to sanctify their couple relationships, and how their couple relationships influence their God images and spirituality. This study explores (1) participants' perceptions of the Christ-groom image; (2) how participants personally relate to the Christ-groom image; (3) how participants sanctify their intimate relationships through this metaphor; and (4) conflicts and ambiguities around the metaphor as applied to participants' intimate partner roles and relationships and to their spirituality. Findings are interpreted through Hermeneutical Theory.

\subsection{Conceptual Framework}

Hermeneutic Theory and the hermeneutic circle were used in crafting interview questions and analysis. This theory asserts that meaning, once recorded, is independent of the author's intent but is open to an assortment of interpretations that fit within the framework of the reader [29,30]. Early conceptions of the hermeneutic circle included understanding the parts of the sacred text in context of the whole text [29]. Later conceptions included the text's historical and cultural contexts [29]. Heidegger re-conceptualized the hermeneutic circle to include understandings of our lived experience, 
claiming that we can only understand objects that are embedded in the world through dasein, how we exist in the world; Gadamer added how our understanding of the world is linguistically mediated [29].

Objects (e.g., phenomena, text, artwork, etc.) are situated within the world of the person seeking to understand them. The individuals seeking to make meaning of any object bring with them presuppositions or "prejudices" based on former knowledge, experiences, and corresponding expectations [10,29-31]. Furthermore, understanding is never complete or certain. Individuals' understanding of the object is continually evolving as the interplay among their presuppositions, the object itself, and new information from the world informs the interpretation: the hermeneutic circle. It is through the hermeneutic strategies of interpretation that the gaps between theology and everyday life are bridged. Everyday life experiences and prior knowledge "presuppose" meanings in the text. The text, reinterpreted through the lens of new experiences, takes on new meanings. In this way, a single text or phenomena is polysemous or capable of producing multiple interpretations [10]. These interpretations provide a lens for interpreting life experiences as well, and so interpretation of text and life experiences are continuous and reciprocating.

The divergent interpretations of the Christ-groom metaphor by Evangelical authors and commentators illustrate the hermeneutic processes and epistemological and ontological presuppositions. The readers' ontological assumptions about "being"-e.g., women and men simply "are" designed to fill specific roles or men and women "are" equally equipped to fulfill multiple roles-serve as a lens to interpreting the text. Epistemological positions about the validity of ways of knowing also influence the interpretations of both text and lived experience. For example, the more conservative Evangelical authors believe that we can only find the truth by a spirit inspired "correct" interpretation of scripture. This is particularly evident in backlashes to Evangelical feminism that urge Christians to "recover" biblical manhood/womanhood, assuming that there is just one, correct way that is biblical [19]. Evangelical feminists tend to be more open to multiple interpretations that correspond to the beliefs and situation of the reader $[15,18]$. Hermeneutical processes of how Evangelicals interpret scripture have been used to study views on abusive marriages [32], gender negotiations [33], and Evangelical authors' approaches to wifely submission and corporal punishment [10].

\section{Methods and Procedures}

This study is part of a larger, mixed-methods study that investigated how family based God images and biblical metaphors were interpreted and applied to family roles and relationships. Of the 575 participants who took a survey on their perceptions of God and family based biblical metaphors, a sub-sample of 18 was interviewed for the larger study. Fifteen Evangelical participant interviews were used for the present study because their interviews yielded rich and meaningful applications of the Christ-groom metaphor to their own lives and relationships. Mainline and Liberal participants did not find the metaphor specifically applicable to family life, so their interviews were not used. A constant comparative method of data analysis was used to explore the research questions.

\subsection{Participants}

Participants for the larger mixed methods study were recruited via church bulletins and email directories in the Midwest as well as through listserves that cater to Christians throughout the United 
States. This qualitative study was composed of a sub-sample of 15 Evangelical participants who lived within three hours of the researcher and indicated that they experienced God through a family metaphor. Twelve of the fifteen indicated on the survey that they had a "husband" God image, but all of them talked in the interviews about the significance of the Christ-groom metaphor in their lives, so all were included. Although it was an option, none of them checked "wife" or "spouse" as one of their God images. Evangelicals were not identified as participants at the outset of the study. Rather, interviews that contained rich and meaningful descriptions of how the Christ-groom metaphor informed their lives, relationships, and spirituality were selected for analysis.

There were 9 women and 6 men that ranged from age 18 to late seventies whose interviews were used for this study (See Table 1). All of them were married, had been married, were engaged, or-in one case - had been engaged but was single at the time of the interview. All of the participants were highly religious as indicated by self-reports on the importance of religion to them and the level of their religious involvement. They were also White because it was White participants who lived within three hours of the researcher and agreed to be contacted for the interview.

Table 1. Description of participants.

\begin{tabular}{lcccl}
\hline \multicolumn{1}{c}{ Name } & Sex & Age & Marital Status & \multicolumn{1}{c}{ Affiliation } \\
\hline Aida & F & $18-39$ & Married & Non-Denominational \\
Crystal & F & $18-39$ & Married & Pentecostal \\
Jacob & M & $\geq 60$ & Married & Christian \& Missionary Alliance \\
Jacquie & F & $40-59$ & Married & Christian \& Missionary Alliance \\
Janet & F & $40-59$ & Married & Lutheran \\
John & M & $18-39$ & Married & Evangelical \\
Josiah & M & $18-39$ & Single & Pentecostal \\
Leah & F & $18-39$ & Engaged & Baptist \\
Lynn & F & $\geq 60$ & Single & Nazarene \\
Macy & F & $18-39$ & Engaged & Pentecostal \\
Mark & M & $\geq 60$ & Married & Independent Fundamental \\
Bob & M & $\geq 60$ & Married & Presbyterian \\
Sharon & F & $40-59$ & Married & Independent (similar to Baptist) \\
Terrence & M & $40-59$ & Married & No Denomination \\
Valerie & F & $40-59$ & Married & (Fundamentalist beliefs) \\
\end{tabular}

The participants were all Evangelical Protestant according to classification by Steensland et al., whose system accounts for significant differences among religious groups by considering historical development of affiliations and not lumping all "non-denominational" individuals together into a single "no demonimation" category [34,35].

\subsection{Procedure}

All participants took an anonymous online survey. At the end of the survey, they were invited to leave contact information if they were willing to participate in qualitative interviews. Participants who 
left contact information and lived within three hours of the researcher were invited to participate in a follow-up interview. Interviews were conducted at a time and place convenient to the participants (coffee house, home, library, etc.), were recorded, transcribed, verified, and coded by the researcher. The interviews ranged from 45 to 95 minutes, were semi-structured and included the following general questions that relate to this study:

(1) In your survey, you indicated that you sometimes think of God as a husband. Could you tell me more about that image?

(2) Describe what kind of a husband God is to you.

(3) How does/will Jesus compare to your natural husband (women) or to you as a husband (men)?

(4) How does/will God as husband/groom impact your marital relationship?

(5) How do you think you came to view Jesus as a husband?

Questions were modified for the three participants who did not indicate in the survey that they had a "husband" God image but brought it up in the interview. For example, "You mentioned earlier that you have tried to think of God as a husband, but struggled. Can you tell me more about that?" Follow up questions asked for examples (Can you describe a time when you felt "protected" by Jesus?), elaborations (Can you tell me more about what feels "weird" to you about the Christ-groom image?), and clarifications (I hear you saying that in your everyday life, you don't really think of Jesus as a husband, but you did mark "husband" in the survey. Can you help me understand that?). Follow up questions were intended to elicit rich, descriptions and interpretations from participants and to "break through" commonly heard, but unreflective rhetoric heavily present in the Evangelical culture. I did this by highlighting apparent discrepancies in the participants' interpretations so that I could hear the hermeneutical processes used to reconcile interpretations of the metaphor with their lived experiences (e.g., Earlier you told me that you believe God will bless you for following the leadership of your husband as the church follows Christ, but I also hear you saying that you believe you are better than him at making important family decisions. How does that work for you?).

\subsection{Analysis}

The analysis procedure was the constant comparative method and involved a constant interaction between the sampled text and analysis procedure. Data were collected and analyzed for emerging themes or categories, and looped back into the data collection [36]. When interesting data emerged from one interview, subsequent interviewees were asked if and how this information related to their own perceptions and experiences. Validity was conceived as the ability of the knowledge claim to withstand falsification attempts [37]. I rigorously pursued falsification attempts to emerging knowledge in the following ways: (1) asking the participants to validate and clarify their responses on the survey before asking more in-depth questions based on survey responses; (2) playing devil's advocate in the interviews and during analysis by looking for examples of the knowledge claims not being true; (3) following-up on apparent contradictions and incongruence; (4) asking for specific examples of claims that participants made of their experience of God and family relationships; and (5) co-constructing potential interpretations of knowledge with the participants in the interviews and in consultation with colleagues during the analysis. 
After reading the transcripts multiple times, I analyzed the texts for emerging themes. Basic descriptions of the participants' responses were noted under general categories (e.g., Jesus is like a husband). Within these general categories, meaning units were categorized and given descriptive names (e.g., Jesus pursues me, Jesus gets jealous of my attention). From these categories of meaning units, themes emerged that gave structure to the participants' experiences (e.g., Jesus can be like a passionate lover) [38].

\section{Findings}

Although the questions asked specifically about the Christ-groom God image, responses more broadly fit both the role-specific husband image and a more general lover image (e.g., God is a lover of humanity and individuals). The language in this paper reflects how the participants talked about this image by calling it a husband/lover image or selecting one term or the other as it relates to the theme. Note that even the men chose to use the term "husband" to describe their God image, despite some discomfort in doing so. The ways that participants talked about Jesus as husband/lover fell into two broad categories: (1) description of Jesus as a husband/lover; and (2) sanctification of couple relationships. Both categories contain themes based on the participants' richly described experiences and the interpretations of those experiences as they were co-constructed by the participants and researcher during the interview and developed through analysis. Pseudonyms are used to protect participants' confidentiality.

\subsection{Category One: Descriptions of Jesus as a Husband/Lover}

\subsubsection{Jesus is a Tender and Intimate Lover}

Some participants described Jesus as a romantic lover characterized by a mutual attraction, intimacy, and idealization of the Jesus-lover. Josiah said, "I am seeking my lover, and so it's the same kind of passion, the same kind of tenderness, the same kind of intimacy. I am approaching him with, seeking to be, attractive, desirable..." He later adds, "he's [Jesus] the object, I guess, of desire. His love is perfect and right and good and not small and petty...so there is an absolute, undeniable attraction." While Josiah talked about Jesus being the idealized object of his desire, Macy talked about Jesus as a husband having "an overwhelming amount of love for me, and love and admiration and pride in me and what I'm doing."

There is a storybook quality to these description, and Aida provides her explanation that humans' enduring stories of love and adventure come from a deep seated longing for salvation by the ultimate lover who is powerful and powerfully desirous, capable of consuming love and unwavering devotion. Here is Aida's description:

... I read a book called the Sacred Romance... but it talks about...our desires for the ultimate story, the ultimate adventure, the ultimate love story. ...He [the author] used examples of The Last of the Mohicans, or the, all of those where the hero comes in and saves the day, but you're not sure that it's going to work out till the very end, that adventure, that being loved with abandon or whatever is all rooted around it, and our desire to be completely intimate and really be beloved, cherished. 
She considered her own longing for intimacy in her marriage and makes sense of it through the metaphor of Jesus as lover. Aida believes that God created humans to long for intimacy, in part, because God longs for an intimate relationship with people. Crystal expressed similar sentiments as Aida regarding the human desire for connection and intimacy. Her perception of Jesus as lover was compatible with Aida's but a satisfying marriage allowed her to positively compare her experience of Jesus as lover to her relationship with her husband when she said: "There are moments with God, it's not for anyone else. It's just for me and God and for me and Jesus. And, it's just such a strong sense of intimacy and reciprocal love that I think only can be compared to the kind of love between a husband and a wife." This description is of a deeply personal, exclusive, emotional connection.

\subsubsection{Jesus Is a Pursuing, Passionate, and Desirous Lover}

The consuming love and devotion of Jesus as lover is intensified in this theme. Longing becomes raging passion, intimacy becomes a desire for such closeness that it threatens to fully envelope, anticipation becomes angst, exclusivity becomes all encompassing, and pursuit borders on obsession.

John did not personally access the metaphor of Jesus as lover but did have an image of God as a lover of humanity, of "being madly in love, greatly desiring a relationship, and maybe we only do crazy things to get it, because that's how much it matters. It's passion that's pursued." Aida talked about how a female Christian writer of the middle ages, "was condemned for her very passionate descriptions of her relationship with God as that was just unheard of, and yet God does want intimacy... That's why we seek out intimacy in relationships."

Although the desire for intimacy is shared with the last description of Jesus as lover, this image includes potential for deep suffering. Jesus as the passionate pursuing lover more openly considers the possibility of rejection, unfulfilled longings and ultimate aloneness. Aida expresses her longings as, "...that desire for adventure and passion and being known wholly, w-h-o-l-1-y, without being rejected...". Consuming love characterizes this description, but also a longing for reciprocation and fear that the lover's level of passion may fall short, causing emotional imbalance.

\subsubsection{Jesus is a Companionable Friend}

Some participants described Jesus as a constant, companionable partner who can always be counted on to be there. Macy used words like "stable" and "always there" to describe Jesus as partner, and Valerie also said that she thinks of Jesus as a "constant companion" who loves her the way she is, although she qualified that this is more of a friend image than a husband-as-companion image. The relationship is experienced as a cooperative one where there is mutual comfort and help. For some people, this was experienced quite literally as Sharon described when she was asked if she ever thinks of Jesus as a husband:

For the two dear friends that are widows and one that is single, yeah, I do. And I know how one years ago, she put on a little, an older lady, widowed, and she put on a ring and sort of had a little ceremony with her close friends to say he [Jesus] is my husband now. So I sometimes do [think of Jesus] as being a helpmate, but also God, not to take away the 
magnitude of God, I mean that we can't even fathom him, but also being right there beside my friend.

Later in the interview Sharon talked about her own experience of Jesus as warm and comforting when she is in bed alone, saying, "Then it's my comfort or my thinking about the warmth of God, and he is with me."

Others, such as Jacquie, expressed a struggle in reconciling this image of Jesus as a companionable partner to Jesus as a deity. She describes Jesus as "the companionate of marital relationships, going to each other for discussion, talking about decisions, planning, that type of stuff." When asked how Jesus is in relation to her she said: “...more of a companion, even though I still see Him as the head. More like the traditional head of a family, and I know that's getting into language that I don't necessarily know how that fits into my thinking."

Jacob had a distant, conceptual connection to the husband metaphor, but said that he thinks of Jesus pursuing him in a way that a man might pursue a close friendship with another man characterized by "close camaraderie" and mutual support. He added that there is often a sense of purpose in these partnerships, such as joining a team or accomplishing a task. Enduring love and compatibility are the hallmarks of this description.

\subsubsection{Jesus is a Sacrificial and Forgiving Partner}

Jesus as a sacrificial partner was present in many of the descriptions. In the passionate lover descriptions by Aida, Jesus is the one who prepares the sunrise for his lover and then waits, only to find that she does not appear. Yet, he continues to do it every day in hopes that his lover will eventually take notice and reciprocate his affection. Jesus is described as the one who does not need help, but partners with them anyway to provide help and comfort. When Lynn was asked to describe the characteristics of the "groom" (what she called Jesus), she said, "willing to trade your life for the welfare of the bride, to give your life for the welfare of the bride, to cherish and honor and, you know, that whole thing." She also said that, although this is her concept of Jesus as a groom, she has trouble experiencing it because neither her father nor her two husbands were sacrificial. She did say about God that "He just is amazingly forgiving. Forgiving! ... and always gives you another chance." Tolerance of the other's failings is another component of this image. Leah's image of Jesus as sacrificial partner was also more conceptual than experiential, and she noted the limitations of her concept of Jesus as a husband:

So what kind of husband is Jesus to the church? Um, sacrificial love, lays down his life, kind of pursues us as sinful people when we go off the tracks, forgiving, and this is coming out of Ephesians 5 and stuff we talked about in [marriage] class, but it's a very limited picture of Jesus as husband. I mean, human husbands do a lot of normal things like wash the dishes and pick up the kids and earn a salary, and I don't think of any of that with Jesus. It's just this love and sacrifice imagery drawn on the gospels and the crucifixion and Ephesians 5, so it's like a very narrow picture of what a husband could be, leaving out tons of other things that would apply to human husbands. 
Terrence also talked about Jesus as a sacrificial partner as a concept rather than an experience. He framed his concept in a parable of Jesus and then interpreted it. In this parable, the man sells everything he has to buy the field, so he can have the treasure, and Terrence thinks of Jesus in this way-sacrificing all to purchase the world and to have him - the treasure, the bride. Some of the descriptions of Jesus as a sacrificial partner are experienced, but most are described as concepts that are believed but not explicitly experienced. This is also true of the next theme which is closely related to Jesus as sacrificial partner.

\subsubsection{Jesus is a Provider and Protector}

This theme addresses some of the practical elements of relationships with an emphasis on roles. Sharon articulated this theme when she talked about how she first thought of Jesus as a husband because she had a need for a provider and protector. She referred to hearing a noise during the night and needing someone to go and check it out, typically her husband's role. She described the things that she needs and how her husband, and then Jesus as husband, provide for these needs:

Well, probably I still, maybe this is non-traditional for today, but it's traditional from years ago, see the husband as more the protector of the family. The one, who in our house, makes sure that the taxes get done, and certain...you know, every family divides things out differently, but he probably takes on more of those things. ...Like the buck stops with him, so to speak. So I guess I see it, not just only for my single friends [thinking of Jesus as husband], but also for me and my loving husband. ...Being sure that things are being provided for, the main bacon bring homer (chuckles).

Sharon said that she mostly thinks of the husband image in relation to her widowed friends, and seemed open to Jesus as husband providing both companionship and provision for her in the event that she would need it. It is as if Jesus is a proxy for when her husband is not serving in the role of provider and companion, as in the case of her widowed friends.

Macy, yet unmarried, also commented on Jesus as a providing and caretaking husband. She talked earlier about Jesus as a tender and intimate lover who admires and loves her but also thinks of Jesus as husband in a very functioning way, saying: "CCause like when I envision being married to someone, a husband, I think of growing together, and I guess that's how I see God-helping me grow-and granted, I'm not helping God grow! (laughs). ...And also, that stereotypical husband looking out, looking out for his spouse, protecting and also, like a father, guiding."

Similar to issues raised under the theme of Jesus as companionate partner, Macy discussed the inequality between her and Jesus as husband. Jesus provides growth, protection, and guidance for her, but she cannot reciprocate because Jesus does not have these needs. This major limit of the metaphor-God is not human and therefore does not have the same needs and limitations as husbands - was especially prominent in this description. 


\subsection{Category Two: Sanctification of Couple Relationships}

\subsubsection{Jesus as an Ideal Intimate Partner “Should” Influence My Marital Relationship}

Participants were in strong agreement about what constituted the "ideal" intimate partner as informed by the metaphor of Jesus as a husband/lover: the description of the sacrificial and forgiving husband who lays down his life for the bride. Some generalized the ideal for either marital partner but most talked about it as a role specific to husbands. This was especially true for participants holding more traditional views of marriage who emphasized the husband's role of sacrificing for the wife and being tolerant toward her.

Terrence, a traditional fundamentalist man, asks himself, "Do I love my wife the way that Christ loves the church? That should be my purpose, you know? I would say that's an area where Jesus gave his all, and that I need to go a lot more, too." Although the Jesus-husband image was not a salient one for him, Jacob also said that the metaphor sometimes causes him to stop and wonder if he is showing the kind of love and respect for his wife that he should. More traditional wives also applied this metaphor to their husbands as an ideal. Valerie, who believes in gender hierarchy in marriage, said that she usually does not personalize this metaphor but, when things are not going well, she will think about how her husband ought to be treating her with "love, adoration, and respect" as Christ did to the church. Janet, divorced, said that she did use the metaphor of the church being the bride as an ideal for her own role as a wife but that her independence and self-reliance "got in the way".

Although some participants viewed this metaphor as an ideal that they should aspire to in marriage, not all seemed concerned when they fell short of that ideal. Janet, for example, said that her independence and self-reliance got in the way of her being the kind of wife that the metaphor calls for, but then added that she does not think that it was bad to be that way, just that it was not what her husband wanted. Leah who was engaged and professed her belief in a literal application of some of these principles (such as male headship and submissive wives) also noted how her mother had tried this with her father, and it "did not turn out well", concluding that "I feel like I can only do so much thinking about it, and I'll just have to wait till I am married and find out what it looks like." Jacquie says that she does not make the parallel because "if it's not black and white in the Bible, why should it be a black and white issue for us...so let's just move on and quite arguing about the grays." Sharon and Crystal both said that thinking of Jesus as a husband should make a difference for what kind of wife they try to be, and Crystal laughingly added, "We would have to ask my husband if it influences the kind of wife that I actually am!” These women's interpretations were less gender specific and more about both partners aspiring to general ideals demonstrated by Jesus, such as valuing the relationship and intimacy with their partners.

\subsubsection{How I Sanctify My Marriage though the Metaphor of Jesus as a Husband}

Some participants talked about specific ways that they sanctify their marital relationships through the metaphor of Jesus as a husband. These occurred mostly through "Manifestations of God" in their marital relationships but also through "Sacred Qualities" [20].

Marital sanctification through the husband God image was manifest in both the marital structure and relationship. Valerie, for example, said that she submits to her husband's final decisions because 
of the metaphor of the church-bride submitting to the Christ-groom. Terrence said that he will include his wife's name on email messages that he sends as a way of crediting her or honoring her and seeing her as part of an "us" rather than just "me, me, me" and that this is consciously done because Christ died for her and told husbands to love their wives as Christ loved the church. Both people structured their relationships hierarchically as a way to manifest the relationship between Christ and the church. Macy applied the metaphor to both husbands and wives and speculated about how it influences her to hope for an unselfish "us" orientation in her marriage.

God was also manifest in marriage with regard to how participants tried to love and share intimacy with their partners. Lynn consciously tried to show unconditional love to her second husband as she believed she had been loved by Jesus, but said she was not able to do it because she was still an "immature Christian". The manifestation of God took an interesting turn with Lynn who then said that she would expect more love from her spouse, as Jesus loves her.

...the biggest difference now is that I deserve to have an equal love that I give. I deserve to get an equal love to what I give. And that was never true. They say that in every marriage - somewhere I read this - that there's someone who loves more. You know, if it's cold at night, they're the one who gets up and shuts the window. And I was always that person. I was always, it's of my nature to do things for people. I'm a caregiver. You know, that's within me, and I deserve that back, and the relationships would evolve, but I never got enough, or felt I got enough of what I felt I was giving, because, then again, it was conditional. It you loved me, you would do that for me because I do it for you all the time, that kind of thing.

Aida related deeply to what she perceived as Jesus feeling rejected by her sometimes - when she did not have time to pray or attend to spiritual things. At the same time, she felt rejected by her own spouse and struggled to manifest God within the difficulties of her marital relationship, saying:

I know that when I have tried to...(cries)...initiate intimacy and he pushes me off, or like, 'what's up?' You know? I don't know what's going on in his mind. I think that we all do need intimacy, and I do want to be conscious of his needs, and at the same time I'm...(struggles with tears)...that, that kind of vulnerability...opens you up to getting hurt (voice breaks)...

Aida says that her own failure to communicate with God through prayer or spiritual activities helps her be more patient with her husband and continue participating in the relationship, even in the face of feeling ignored or rejected.

Some participants, like Sharon, ascribed sacred qualities to their marriages more globally. She thinks she may value the relationship more because it is symbolic of the spiritual relationship between Christ and the church. She thought that this would matter the most in difficult times because she might be more willing to invest in a marriage that was viewed as sacred. This fits with previous findings that show individuals sanctifying marriage through direct applications (theology or Jesus' example) and a more general ascribing of "sacredness" to marriage [26]. 


\subsubsection{My Intimate Relationships Influence how I Perceive Jesus}

Sanctification is about infusing human relationships with spiritual significance and meaning [20]. However, participants in this study talked a lot about how their couple relationships impacted the paths and possibilities of experiencing God-for better or for worse. Crystal says that she could not really experience God in some ways until she became a wife, at which point she thought, "Oh, so this is what the scripture means when it says God is like my groom! Like, you know, my spouse, my soul mate or whatever. So that really made a big difference [in how I experienced God].” Aida felt emotionally disconnected from her husband and believed that it impeded her ability to discover God's love for her. She says, "And I still want to discover more of how passionately, how unreservedly God loves me...but I don't feel that I've experienced it in such a way that I could speak with authority...I just wish I had something more concrete or personalized. That's just something I, ideally, would like..."

Aida expressed a desire that is much more demanding than that of closeness or connection. She wants to be completely and wholly understood and still be accepted. At the same time, she recognized how she is sometimes a dismissive lover in relation to Jesus in the way that her husband is often dismissive of her, saying, “... when I feel pushed off or ignored by my husband, that that's exactly how God feels when I run through my day without giving him a second thought. And so, in a way, that neediness has put me in touch with how much God loves us, and yet he doesn't force himself on us." The experience that Aida has of her husband changes how she is thinks about and acts out her spiritual life. She takes time to think about God and pray more in response to feeling brushed off by her husband and believing this to be Jesus' experience of her.

Some participants avoided thinking of Jesus in a husband role because of their experiences with intimate partners. Lynn, for example, describes sex as being a problem for her and how that prevents her from thinking of Jesus as a metaphorical groom. She says:

...sex has always been my downfall. I mean it has always been a very important part of my life and a very controlling part of my life and has consistently gotten me into trouble (laughs) — where I didn't want to be, but, you know, I went willingly. And that's probably part of the reason I have a total avoidance of thinking of the groom role...much at all. Because to me sex and marriage are, just like that [holds up crossed fingers], and I cannot even conceive of a marriage without it, so...I can't approach it because it's just too worldly to think of!

Janet said that the poor example of her father and disappointment of her ex-husband makes her confused about the husband role and that not thinking of Jesus in an intimate role protects God from some of her negative feelings about husbands. Several of the men talked about having difficulty accessing Jesus through the husband metaphor for reason of being heterosexual men. Terrence believed this was him being "carnal" or spiritually "immature", and wanted to be able to access this God image. Josiah similarly struggled with the metaphor saying, “...it's a little strange with the sex difference. I'm the wife (laughs), but that is the reality of the metaphor. It is right out there." He does access it in some ways, referring to it as a "tender" way to experience God. Jacob reframes the metaphor as a man pursuing another man in friendship and for a united purpose, while John says that the metaphor is "headsy" for him and jokes: 
I have not, in my mind ever, like, had a wedding dress on...I've been able to go so far as to like the idea of God pursuing me, passionately wanting to participate in life with me, and me sometimes receiving that full on... and other times confused and walled. So there's a point at which the metaphor stops for me.

Participants' relational experiences appeared to impact the possibilities for how they could conceive or relate to God, particularly in family based metaphors. Some perceived this as something to overcome while others simply saw it as an un-useful way for them to access God.

\subsubsection{Jesus as Intimate Partner Has Limited Application to My Marital Relationship}

Many participants ran into the limits using this metaphor to sanctify their relationships. Leah talked about the many practical things that human husbands do - like washing dishes or earning a salaryand how thinking of Jesus in a husband role is limited in helping to guide or interpret those parts of the marital relationship. Most of the participants struggled with the metaphor because it includes a perfect deity in relation to them rather than imperfect people relating to each other.

Jesus is perfect, but husbands are not. Sharon introduced the challenge of viewing Jesus as a companionate partner. She described Jesus as a companionate partner with whom she has a cooperative relationship but then reconsidered and said, "I mean, certainly God's going to be God whether we cooperate or not, and so I can't put myself on a level of being on his, I guess I could be on his team, but it's not quite the same. (chuckles) It just doesn't feel...it takes away from who God is, to me." She says that she would be "ready and willing" in response to Jesus as husband, but that she does not want to be a doormat in her relationship with her own husband. She says that she is safe to always be ready and willing with Jesus, because he would never take advantage, but she cannot be sure of that with a person.

Jacquie easily describes Jesus in egalitarian language such as "going to each other" and "talking about decisions" while simultaneously referring to him as the head who empowers her and guides her in making decisions. The struggle of the metaphor is about its implication for family life as she says she is not sure about complementary or egalitarian views of marital relationships - but that couples should just do what works. Crystal expresses a similar incongruence when she says:

I always feel confident that when my reaction to my husband and to God is always going to be reciprocated. When I feel drawn to God and drawn to my husband, I know that God will always be drawn to me and vice versa. And that's not always true about my husband because...it's God! So there are definitely things that are different because God never makes a mistake, and my husband does make mistakes (both laugh). And, you know there are things about my natural husband that I think, I wish he wouldn't think that way, or I wish he wouldn't do that, but, although there are things about God that I don't understand, but there again, because it's God, I can say, well that's God, and I just don't know everything. With my natural husband, you know, I can say, I think I do know, and my way is better! (laughs). 
Leah is confronted with incongruences between her church's teaching, her literal biblical beliefs, and her mother's experience as she tries to work out with her fiancé how they will be as a married couple. She grapples openly with this when she says:

My church is very big on headship and submission, and guys are more vocal and out there while we're supposed to follow... But then I look at my parent's relationship, and I look at my mom because I talk to my mom all the time about this. And I think my mom in retrospect [believes] that she over-submitted to my Dad. She kind of bought into all this Christian teaching about, you know, wives submit, and did that for twenty years, and I think now she looks back and says that it was terrible. She got kind of squished along the way. She enabled my dad to make really bad parenting decisions, and she now thinks that's not what submission means, that the wife needs to be giving feedback, needs to not let the husband do whatever he wants, that he needs a wife that's giving him intelligent, helpful input. So I'm trying to figure out, what do I think? Do I go with kind of my church with submission?... Do I go with my mom's view? Theoretically, husband is leading well and putting the wife first and sacrificing where needed and serving her and humble, not thinking he has it all figured out but wanting her input. And likewise, theoretically the wife is respecting the husband and supporting him and affirming and encouraging, but, also, you know, giving input... but that's a theory, and I have no idea what it actually looks like in practice! (chuckles)

Aida concludes that she seeks for something in a husband that only a god can provide- - being fully known and accepted. Although her perception of God is that he ardently pursues intimacy with her and has the ability to know her and unconditionally love her, she seeks this from a human lover that cannot possibly meet her expectations. As Aida considers her need for complete intimacy and her attempts to find it in her marital relationship, she concludes this way: "I have to say that God is all that we need. He is. He provides everything. ... I don't think I should be looking to satisfy all my needs and expect some finite person to be everything I need."

Crystal also noted that sometimes her husband is too busy to show an interest in the small things going on in her life, and, although she believes Jesus always has time for those things, she notices that she projects this on to Jesus by not bothering him with praying about trivial things. She added that when her relationship is really close and supportive with her husband, she has context to want that in her spiritual relationship with Jesus as well. This shows how participants were sometimes challenged by extrapolating the Jesus-husband metaphor because of the imperfections of their partners or themselves.

Jesus is perfect, but I am not. Participants got stuck as they projected the metaphor of their couple relationships back on to relating to God or Jesus. Macy had talked about how Jesus helping her grow informed how she wanted her future husband and her to help each other, but added ruefully that she does not help God grow and how that is different. Sharon noted the limitations of the metaphor in how she would handle her personal struggles differently with her husband compared to Jesus when she said, "I'm thinking when it's my husband, if there is an issue, I'd probably say... something like, 'How are we going to handle that?' And, with God it's more like, 'What do you want me to do? How are you going to help me through this?'” 
Men who were more gender traditional and literal with the metaphor also expressed their anxiety about not being enough "like Christ" in their relationship with their wives and their spiritual relationships. Terrence appeared to agonize over where he perceived himself to be lacking as he related to his wife, saying, "You know, he [Jesus] died for her...You say, "well, I might be willing to die for her, but am I dying?' That's a different category (laughs ruefully)." He believed that his own will and desires should be sacrificed or "die" in order to better serve the needs of his wife, and worried that he was not doing this enough. Terrence also talked about his pride getting in the way of submitting to God, implying that it is in the same way that it might be hard for wives to submit to their husbands. Other men talked about wanting to be more "Christ like" husbands but without the intensity displayed by Terrence. Jacob, for example, said that he occasionally thinks about how he should better appreciate his wife's gifts as Christ appreciates the diverse gifts in the "body of Christ" or bride. This was the mirror image of women's perspective of the limitations of the metaphor: I do not relate to my husband as I would to Jesus because my husband is imperfect. Men sometimes paused in their comparison of Christ to themselves as husbands to acknowledge the unfair expectations that the metaphor could raise.

\subsection{Re-contextualizing the Jesus as Intimate Partner Images}

The salience of the husband/lover God images were very different across the sample as demonstrated by the importance of it compared to other God images and whether it was an image that was conceptual or experiential. Table 2 shows participant by other God images held by the participant, whether the husband/lover image was conceptual or experienced, and participants' religious affiliations.

Table 2. Husband/lover images with related participant variables.

\begin{tabular}{|c|c|c|c|}
\hline Name & Other God Images & Conceptual or Experiential & Affiliation \\
\hline Aida & $\begin{array}{l}\text { Father } \\
\text { Mother }\end{array}$ & $\mathrm{E}$ & Non-Denominational \\
\hline Crystal & $\begin{array}{l}\text { Father } \\
\text { Mother }\end{array}$ & $\mathrm{E}$ & Pentecostal \\
\hline Jacob & $\begin{array}{l}\text { Father } \\
\text { Brother }\end{array}$ & $\mathrm{C}$ & $\begin{array}{l}\text { Christian \& Missionary } \\
\text { Alliance }\end{array}$ \\
\hline Jacquie & $\begin{array}{l}\text { Father } \\
\text { Mother }\end{array}$ & $\mathrm{C}$ & $\begin{array}{l}\text { Christian \& Missionary } \\
\text { Alliance }\end{array}$ \\
\hline Janet & $\begin{array}{l}\text { Father } \\
\text { Brother }\end{array}$ & $\mathrm{C}$ & Lutheran \\
\hline John & $\begin{array}{l}\text { Father } \\
\text { Mother } \\
\text { Sibling }\end{array}$ & $\mathrm{C}$ & Evangelical \\
\hline Josiah & Father & $\mathrm{E}$ & Pentecostal \\
\hline Leah & $\begin{array}{l}\text { Father } \\
\text { Brother }\end{array}$ & $\mathrm{C}$ & Baptist \\
\hline Lynn & $\begin{array}{l}\text { Father } \\
\text { Brother }\end{array}$ & $\mathrm{C}$ & Nazarene \\
\hline Macy & $\begin{array}{l}\text { Mother } \\
\text { Father }\end{array}$ & $\mathrm{E}$ & Pentecostal \\
\hline
\end{tabular}


Table 2. Cont.

\begin{tabular}{|c|c|c|c|}
\hline Name & Other God Images & Conceptual or Experiential & Affiliation \\
\hline Mark & $\begin{array}{l}\text { Father } \\
\text { Brother }\end{array}$ & $\mathrm{C}$ & Independent Fundamental \\
\hline Bob & Father & $\mathrm{C}$ & Presbyterian \\
\hline Sharon & $\begin{array}{l}\text { Father } \\
\text { Mother }\end{array}$ & $\mathrm{C}$ & Independent (similar to Baptist) \\
\hline Terrence & $\begin{array}{l}\text { Father } \\
\text { Brother }\end{array}$ & $\mathrm{C}$ & $\begin{array}{l}\text { No Denomination } \\
\text { (Fundamentalist beliefs) }\end{array}$ \\
\hline Valerie & Father & $\mathrm{C}$ & Non-Denominational \\
\hline
\end{tabular}

"Father" was a God image for all participants and, by far, the most salient for them. Although "mother" was a God image identified by six participants in the survey, it turned out to be inaccurate or weak when it was explored in the interview. Brother was also a very weak, limited God image upon more rigorous inquiry into its significance and application in participants' lives. The father God image avoided many of the relational, spiritual, and theological conundrums that were present in the husband image - particularly with regard to power. Fathers are generally not viewed as equals to children, and so participants could more easily talk about deferring to God's wisdom, seeking help and submitting to authority when they related to God as a father and not a husband/lover. Participants talked easily about God as a father while they often struggled or qualified talking about God or Jesus as a husband/lover.

The husband image of God was also more conceptualized than experienced. It is not surprising that of the four participants who talked about experiencing God as a husband/lover, three were Pentecostal - a religious tradition with a heavy emphasis on emotional expression in worship and in their experience of God. All four participants who experienced God as a husband/lover described used words like "passion", "desire", and "intimacy" to describe their experience of their spiritual relationship. Aida, the non-denominational participant who experienced God emotionally, described reading a lot of literature that supported the idea that God's relationship to people is about universal human needs for unconditional love, acceptance and being "known", things she perceived as lacking within her own marriage. These participants all described feeling loved or special to God, desiring God as God desires them, and projecting their own occasional feelings of neglect or relational imbalance onto how God must feel when they are neglectful.

The eleven who sometimes conceptualized God as a husband/lover varied greatly. They used much of the same biblical language for the husband/lover image as those who experienced God as husband/lover, but stated that they did not access the image on an emotional level. Janet and Lynn purposely avoided this image because of bad relationship experiences in their past. Some participants said that they might benefit from a more salient experience of God in this way. Jacob and John both said that thinking of God as a husband/lover might stretch their understanding of God in ways that would benefit them and their relationships, but it was simply not accessible to them. Bob said that he envied people who experienced God in emotional ways, but said that he never had been able to as he is a pragmatist and skeptic. Terrence viewed his inability to experience God as a husband/lover as a spiritual flaw_-immaturity" or "carnality" - and something that he should overcome. Other participants simply described God as a husband/lover in biblical language and religious rhetoric, 
making the connections commonly made in Evangelical literature, sermons, and music, but did not seem concerned that this God image was not experienced on an emotional level.

Men more often described discomfort with the metaphor in terms of being a "bride" or in a female position while women described discomfort in terms of the sexual implications or implied subservient position of wives in relation to husbands. Regardless of whether God as a husband/lover was conceptual or experiential, all participants discussed how it could be applied to intimate couple relationships_-sometimes as a model and sometimes as incongruent with marital equality ideals.

\section{Discussion and Conclusions}

This study examined the hermeneutical processes by which Evangelicals interpreted the Christ-groom metaphor in light of their lived relationships and spiritual experiences. Participants described Jesus within the Christ-groom metaphor as: (1) tender and intimate with desire for them or humankind; (2) relentlessly and obsessively pursuing them with a mad love and passion for them, potentially experiencing rejection from them and suffering as a result; (3) a stable, companionate partner; (4) continually sacrificing and generously giving without asking for anything in return; and (5) providing for their needs, even though they cannot reciprocate.

Participants used the husband/lover God image as a way to "sanctify" or perceive spiritual characteristics or significance in their marital relationships [20]. Participants viewed God as being manifest in their couple relationships (e.g., the sacrifices I make for my spouse represent Jesus's sacrifice for me) and by ascribing sacred qualities to it (e.g., spouse is a "gift" from God). They described how Jesus is an example of how they "ought" to be in their marriages - such as sacrificial, unconditionally loving, and invested in their partners. Some applied the metaphor to the structure of their marriages literally and viewed the sacrificial leadership of husbands and submission of wives as manifestations of Jesus's relationship to humanity. Others held to the metaphor more loosely or openly struggled with how to apply the hierarchal components of the metaphor to marital relationships they viewed as equal. Besides the structure of the marital relationship, participants also talked about how the metaphor influenced their ways of relating - such as being more patient or loving with their spouses. Not only did the metaphor influence how they sanctified their marital relationships, but some participants projected things from their marital relationships back onto how they related to Jesus - such as feeling connected in their marriages and wanting to pursue a close spiritual connection to Jesus as well or feeling ignored by a spouse and feeling spiritually distant.

\subsection{Hermeneutical Interpretive Strategies}

There were many conflicts and limitations in the extrapolation of this metaphor to marriage and spirituality. When understandings of themselves, relationships, God, and spirituality were in conflict, participants used interpretive hermeneutic strategies to creatively resolve them. Differences in their overall approach to reading the Bible (e.g., the literal message is important, it is the principle that matters, etc.), differences in the salience of the Christ-groom metaphor to them, their own relational experiences, and their personal perception of God's nature together compose the hermeneutic circle. Each of the four components worked in relation to each other to generate interpretations of scripture related to the Christ-groom metaphor, their own relationships, and their spiritual connection. 
One way to resolve incongruence was to reject the importance of applying the metaphor to natural phenomena. Jacquie was well versed in interpretations of the metaphor that proscribed a hierarchical marital structure and could not reconcile it to her more egalitarian marriage and values. She resolves the incongruence by saying that there is no point in getting adamant about what is "gray" in the Bible. She and her husband do what works and don't worry about trying to apply the metaphor strictly. Janet states that she does not apply the metaphor because her lived experience of marriage conflicts with her view of Jesus. She rejects the metaphor to protect a positive God image from her bad experience with a previous husband. This fits with one of the four gender ideologies described in Promise Keepers literature: a pragmatic approach to marriage that stems from a broader interpretation of the Bible that concludes as follows: marriage is sacred and mutual love and respect is biblical, so couples should work together to make their marriages viable [13]. This is also true for interpreting spiritual experiences. John does not find the metaphor very useful in understanding God-quipping that he does not think of himself in a wedding dress - but easily sets it aside for metaphors he finds more useful.

Other participants sought to resolve apparent contradictions between the metaphor and their own relationships by favoring flexible, gender neutral interpretations. They maintained their belief in the Bible as "true" by focusing more on the spirit of the interpretation than the letter of it. Often the incongruence was encountered in the interview itself as when Crystal was describing how Jesus expects her worship and adoration. She stops abruptly, laughs, and says she would be angry if her husband expected the same. In the end, she doesn't seek to resolve it but simply says that she's never thought of it before. She continues to describe how the metaphor helps her understand spiritual things, but easily discards applications that do not fit for her. She, Sharon, Jacquie, and Macy all use the metaphor "when it works" with their understanding of good relationships and use hermeneutical interpretations that are broad, gender neutral, and flexible.

Participants who were not willing to "set aside" the metaphor when it did not fit or to be more flexible in its interpretations wrestled with incongruence the most. Terrence and Josiah, for example, embraced a literal interpretation of both the metaphor and the Bible overall. They were committed to thinking of Jesus as a Groom-husband, but could not really relate to the God image because of being men. Josiah easily related to the metaphor emotionally as he experienced God and spirituality in an emotionally charged way - describing longing for God or feeling deeply loved by God. He said that it is hard to see himself as "the wife" in the metaphor, but adds, "...that is the reality of the metaphor. It is right out there." For him, there is not room for hermeneutical interpretation on this point, and so he focuses his attention on his own experience and how he can adjust to better accept the metaphor as literally written. Terrence goes further with this by interpreting his own ability to fully access the metaphor as inadequate - calling himself spiritually immature. In both of these cases, it is their perceived spiritual "limitations" that must change in light of the metaphor, not the metaphor in light of their human experience of spirituality.

Aida's incongruence is the most striking, because she is suffering from trying to apply the metaphor to a difficult marital relationship, and the outcome is sad for her. She is committed to a specific interpretation of the metaphor as outlined in the books, articles, radio broadcasts, and other materials that she consumes. All of them support a single, inflexible interpretation of the metaphor in which she is heavily invested - a passionately pursuing and jealous lover-God who is capable of capturing her heart and of feeling crushed at her rejection. This causes her to re-interpret her own experiences to 
make them fit the metaphor. She does this by pointing out how her husband is not acting "like Christ", which is why she is unfulfilled in the marriage. However, she also notes that her expectations of him are too high, and that "God is all that we need". She vacillates between her interpretation of other scriptures (God is all we need) and of the metaphor (my husband should take care of my needs, as Christ does for the church), never noting the conflict between the two interpretations. She is critical of herself in her marriage but also herself as a Christian, interpreting her sadness as a reminder of how Jesus must feel when she does not respond to his love for her. In contrast to Aida, Lynn also re-interprets her own expectations in light of the metaphor, but in a positive way. She says that the metaphor of Jesus as an attentive husband changed her mind about what she should expect from a partner: she now believes that she deserves to be loved, as Christ loves her and interprets anything short of that as not worthy of her.

There is evidence that this metaphor has potential to strengthen couples' commitment to each other, encourage unconditional love, patience, and sacrifice for the other. Conceptions of God can also be enhanced by attributing to God the best things about loving couple relationships. However, inflexible interpretations also introduce risks, as participants must re-interpret their own experiences in light of the metaphor and, in this study, were very self-critical in those interpretations. The Christ-groom and Church-bride metaphor remains the organizing concept for marriage in Evangelical theologies and rhetoric, and these findings suggest that narrow, inflexible interpretations may be unhelpful, irrelevant, or even distressing for adherents. Conversely, using the metaphor more flexibly with an emphasis on the broadly positive components of unconditional love, commitment, willingness to sacrifice for the other, companionship, etc. may provide potential interpretations that enhance Evangelicals' relationships and spirituality.

\subsection{Limitations and Future Research}

There are several things that limit this study, all of which suggest ideas for future research. First, the interviews did not reach the point of saturation for each theme. The descriptions of the Christ-groom image repeated to the point of saturation, but that is expected, given how familiar Evangelicals are with this common rhetoric. The ways that individuals struggled with incongruences were repeated as well, but additional interviews with a more diverse sample would undoubtedly further develop those themes. This leads to the second limitation: the homogeneity of the sample. Although it was an intentionally religious sample and focused on Evangelical interviews, participants were all white, from the Midwest and the majority women. Participants had diverse background in terms of marital situation (status, history, and quality of marriage), and that proved to be illuminating in how they interpreted and applied the metaphor (e.g., bad relationships in the past resulted in reported "avoiding" the metaphor presently). A sample that includes Evangelicals of diverse ethnicities, SES, affiliations and marital situations is needed to gain clearer insight into the hermeneutical interpretations of this metaphor, relationships, and spirituality.

Finally, it is important to extend this research to other religious groups that rely on metaphors to develop God images and models for family life. Evangelicals are an excellent starting point as they tend to believe in a more literal interpretation of these metaphors and believe in a very personal, relational God, but more diverse religious groups and types of metaphors should be explored to help us 
understand how they are used - for better or for worse - to influence spirituality, family life, and how individuals approach their everyday lives.

This study (and others on sanctification) show how theology and sacred texts can influence how couples structure relationships and ascribe meaning to family roles and relationships. The present study also demonstrates how family relationships can impact God images and experiences of the Divine. More studies that examine potential reciprocity between spirituality and family life could be especially illuminating to both family and religious professionals.

\section{Acknowledgements}

This study was made possible by the generous funding of the Joseph H. Fichter Research Grant from the Association for the Sociology of Religion. Thanks to Paul C. Rosenblatt for his invaluable support of this research; Kevin Doll and Christopher Ruder for insightful feedback on the manuscript and formatting; and anonymous reviews of the paper.

\section{Conflicts of Interest}

The author declares no conflict of interest.

\section{References}

1. C.S. Lewis. That Hideous Strength. New York: The Macmillan Co, 2008, pp. 315-16.

2. David Kyle Foster. "The Divine Order to Marriage." Focus on the Family. Available online: http://www.focusonthefamily.com/marriage/gods_design_for_marriage/marriage_gods_idea/the divine_order_to_marriage.aspx (accessed on 28 May 2014).

3. David Kyle Foster. "Marriage's Meaning for Believers." Focus on the Family. Available online: http://www.focusonthefamily.com/marriage/gods_design_for_marriage/marriage_gods_idea/marri ages_meaning_for_believers.aspx (accessed on 28 May 2014).

4. David Kyle Foster. "Reflecting our Relationship with God." Focus on the Family. Available online: http://www.focusonthefamily.com/marriage/gods_design_for_marriage/marriage_gods_idea/ reflecting_our_relationship_with_god.aspx (accessed on 28 May 2014).

5. William Bradford Wilcox, and Elizabeth Williams. "The Cultural Contradictions of Mainline Family Ideology and Practice." In American Religions and the Family. Edited by Don S. Browning and David A. Clairmont. New York: Columbia University Press, 2007, pp. 37-55.

6. Susan D. Rose, and Women Warriors. "The Negotiation of Gender in a Charismatic Community." Sociological Analysis 48 (1987): 245-58. doi:10.2307/3711521.

7. Sally K. Gallagher, and Christian Smith. "Symbolic Traditionalism and Pragmatic Egalitarianism: Contemporary Evangelicals, Families, and Gender." Gender and Society 13 (1999): 211-33. doi:10.1177/089124399013002004.

8. William Bradford Wilcox. Soft Patriarchs, New Men: How Christianity Shapes Fathers and Husbands. Chicago: University of Chicago Press, 2004.

9. Eric L. Johnson. "Playing Games and Living Metaphors: The Incarnation and the End of Gender." Journal of the Evangelical Theological Society 402 (1997): 271-85. 
10. John P. Bartkowski. "Beyond Biblical Literalism and Inerrancy: Conservative Protestants and the Hermeneutic Interpretation of Scripture.” Sociology of Religion 57 (1996): 259-72.

11. John P. Bartkowski. "Debating Patriarchy: Discursive Disputes over Spousal Authority among Evangelical Family Commentators." Journal for the Scientific Study of Religion 36 (1997): 393-410.

12. Neal Christopherson. "Accommodation and Resistance in Religious Fiction: Family Structures and Gender Roles.” Sociology of Religion 60 (1999): 439-55.

13. William H. Lockhart. “'We Are One Life,' But Not of One Gender Ideology: Unity, Ambiguity, and the Promise Keepers." Sociology of Religion 61 (2000): 73-92. doi:10.2307/3712091.

14. Pamela D.H. Conchran. Evangelical Feminism: A History. New York: New York University Press, 2005.

15. Rita Halteman Finger, and Kari Sandhass, eds. The Wisdom of Daughters: Two Decades of the Voice of Christian Feminism. Philadelphia: Innisfree Press, Inc., 2001.

16. Lynn Japinga. Feminism and Christianity: An Essential Guide. Nashville: Abington Press, 1999.

17. Virginia Ramey Mollenkott. Women, Men, and the Bible. New York: Crossroad, 1988.

18. Virginia Ramey Mollenkott. The Divine Feminine: The Biblical Imagery of God as Female. New York: Crossroads, 1983.

19. John Piper, and Wayne Grudem. Recovering Biblical Manhood and Womanhood (Redesign): A Response to Evangelical Feminism. Wheaton: Crossway, 2012.

20. Annette Mahoney, Kenneth I. Pargament, Aaron Murray-Swank, and Nicole A. Murray-Swank. "Religion and the Sanctification of Family Relationships." Review of Religious Research 44 (2003): 220-36. doi:10.2307/3512384.

21. Elizabeth H. Baker, Laura A. Sanchez, Steven L. Nock, and James D. Wright. "Covenant Marriage and the Sanctification of Gendered Marital Roles.” Journal of Family Issues 30 (2009): 147-78. doi:10.1177/0192513X08324109.

22. Nicole A. Murray-Swank, Kenneth I. Pargament, and Annette Mahoney. "At the Crossroads of Sexuality and Spirituality: The Sanctification of Sex by College Students." The International Journal for the Psychology of Religion 15 (2005): 199-219.

23. Krystal M. Hernandez, Annette Mahoney, and Kenneth I. Pargament. "Sanctification of Sexuality: Implications for Newlyweds' Marital and Sexual Quality.” Journal of Family Psychology 25 (2011): 775-80. doi:10.1037/a0025103.

24. Christopher G. Ellison, Andrea K. Henderson, Norval D. Glenn, and Kristine E. Harkrider. "Sanctification, Stress, and Marital Quality." Family Relations 60 (2011): 404-20. doi:10.1111/j.1741-3729.2011.00658.x.

25. Alfred DeMaris, Annette Mahoney, and Kenneth I. Pargament. "Sanctification of Marriage and General Religiousness as Buffers of the Effects of Marital Inequity.” Journal of Family Issues 31 (2010): 1255-78. doi:10.1177/019253X10363888178.

26. Michael A. Goodman, and David C. Dollahite. "How Religious Couples Perceive the Influence of God in their Marriage." Review of Religious Research 48 (2006): 141-55.

27. Elizabeth J. Krumrei, Annette Mahoney, and Kenneth I. Pargament. "Divorce and the Divine: The Role of Spirituality in Adjustment to Divorce." Journal of Marriage and the Family 71 (2009): 373-83. doi: 10.1111/j.1741-3737.2009.00605.x. 
28. Paul Froese, and Christopher Bader. America's Four Gods: What We Say About God-And What That Says about Us. New York: Oxford University Press, 2010.

29. Bjørn Ramberg, and Kristin Gjesdal. "Hermeneutics." In The Stanford Encyclopedia of Philosophy. Edited by Edward N. Zalta. Stanford: The Metaphysics Research Lab Center for the Study of Language and Information, 2013. Available online: http://plato.stanford.edu/archives/ sum2013/entries/hermeneutics/ (accessed on 30 May 2014).

30. Jeff Malpas. "Hans-Georg Gadamer." In The Stanford Encyclopedia of Philosophy. Edited by Edward N. Zalta. Stanford: The Metaphysics Research Lab Center for the Study of Language and Information, 2013. Available online: http://plato.stanford.edu/archives/win2013/entries/gadamer/ (accessed on 30 May 2014).

31. Hans-Georg Gadamer. Philosophical Hermeneutics. Translated by David E. Linge. Berkeley: University of California Press, 1976.

32. Shondrah Tarrezz Nash. "The Changing of the Gods: Abused Christian Wives and Their Hermeneutic Revision of Gender, Power, and Spousal Conduct." Qualitative Sociology 29 (2006): 195-209. doi:10.1007/s11133-006-9018-9.

33. John P. Bartkowski. Remaking the Godly Marriage: Gender Negotiation in Evangelical Families. New Brunswick: Rutgers University Press, 2001.

34. Brian Steensland, Jerry Z. Park, Mark D. Regnerus, Lynn D. Robinson, W. Bradford Wilcox, and Robert D. Woodberry. "The Measure of American Religion: Toward Improving the State of the Art.” Social Forces 79 (2000): 291-318. doi:10.2307/2675572.

35. Tom W. Smith. "Classifying Protestant Denominations." Review of Religious Research 31 (1990): 225-45. doi:10.2307/3511614.

36. Sylvia E. Rafuls, and Sidney M. Moon. "Grounded Theory Methodology in Family Therapy Research." In Research Methods in Family Therapy. Edited by Douglas H. Sprenkle and Sidney M. Moon. New York: The Guilford Press, 1996, pp. 64-80.

37. Steiner Kvale. Doing Interviews. Edited by Uwe Flick. Los Angeles: Sage, 2007.

38. Max van Manen. Researching Lived Experience: Human Science for an Action Sensitive Pedagogy. Ontario: Althouse Press, 1990.

(C) 2014 by the author; licensee MDPI, Basel, Switzerland. This article is an open access article distributed under the terms and conditions of the Creative Commons Attribution license (http://creativecommons.org/licenses/by/3.0/). 